\title{
中国願和園における煉瓦彫刻に関する調査研究
}

\section{An Investigation of Brick Carvings in the Summer Palace of China}

\author{
章 俊華 - 高大偉 \\ Jun-Hua ZHANG ・ Da-Wei GAO
}

千葉大学園芸学部 - 頤和園副園長

Chiba University Faculty of Horticulture - Summer Palace Vice-President

Key Words : 1. 棟瓦彫刻 2. 頣和園 3. 調査

1. Brick Carvings 2. Summer Palace 3. Investigation

\section{1. はじめに}

頋和園は世界の庭園の中でも人造景観が豊富で、園林 建築が集中し、保存が完全な皇家庭園である。園内の仏 香閣、長廊、石舫、排雲殿、諧趣園などはいずれも世界 の園林建築の中の逸品といえよう。臨和園の庭園空間は 最も集中的に中国の伝統的造園芸術の精華を具現し、人 造美と自然美とが融合し、中国文化の特色を持つ山水絵 巻を展開している。その素晴らしさは立派な造園技術に 現れているだけでなく、建築物細部の精緻華美な装飾に も見られる。彫刻棟瓦はその伝統的な装飾技術が庭園景 色に適切に応用されたものの一つである。願和園に関す る既往研究は多くの研究成果が見られるが、その大半は 資料による歴史的な研究 ${ }^{1)}$ と現地調査を中心とした扁額、 屋宇や利用者数など庭園空間の特徽と利用状況の研究 ${ }^{2)}$ であった。本調査研究では、頣和園に分布寸る棟瓦彫刻 にある紋様（図案）、場所、意味と寸法などを調査する ことにより、頣和園における棟瓦䧓刻の場所ごとの分布 状況について明らかにするものである。

\section{2. 棟瓦彫刻}

中国の建築用彫刻棟瓦は石材彫刻を模做するもので、 石材彫刻より必要とする労力が少ないためコストが低く、 しかも石材彫刻の耐久性と木材彫刻の精緻さとを持ち合 わせているので、広く使われた。古文献の中で「文様棟 瓦の記載があるが、それは型抜き紋様棟瓦或いは図案 棟瓦の一種で、工芸技法が複雑なため、徐々に彫刻棟瓦 に変化していった。宋の時代の書物「営造法式ににはじ
めて彫刻棟瓦の製造法が具体的に記載されている。元の 時代に入ると、彫刻棟瓦の製造が比較的に盛んになり、 元大都遺跡加ら出土された動物紋様と花紋様の彫刻棟瓦 から見ると、この時代にはすでに䧓刻棟瓦は装飾用とし て使われていた。その後、明の時代の棟瓦製造及び棟瓦 彫刻技術は、相当精巧なレベルに達した。清の時代に入 った頃には、その技術がさらに発展し、「丵花行」とい う専門業種として定着し、彫刻棟瓦はまた俗称花棟瓦と も言うので、それを造る職人は「丵花厈」とも呼ばれた 3)。この時期から䧓刻煉瓦は全面的発展期に入った。作 りが精巧で、題材は多彩で、人工的に作られたにもかか わらず自然美に優れる。南では蘇州、徽州などの棟瓦彫 刻が優れており、影響があり、精巧な作りが特徴である。 北では山西省がその発祥地となっていて、大らかさが特 徵で、都に入ってから民間富豪の邸宅建築の装飾に用い られ、雅豊かな趣になった。その後、このような装飾様 式が王朝貴族の宮殿、官邸建築などに応用されるように なると、徐々に「官式」技法になってしまった（図一1 参照)。

\section{3. 調査の方法}

平成 17 年 3 月 1 日〜 18 日の 18 日間に渡り、北京市園 林管理局、北京図書館、北京林業大学、また頤和園管理 処を数回訪祆た。頣和園に関する文献·資料調査を行い、 その中で、頣和園磚彫芸術（頣和園設計室、願和園文化 研究室 2000) を基本資料とし、《䫝和園》(周維権 1980)、 《顚和園六十景》（李燕芳 1993）、《中国園林建築》（馮 
鐘平 1985)、頣和園的前山前湖（周維権 1980、建築史論 文集NO.5) 、吉祥図案（王立導 1987）、中華吉祥図（葉 応檖ら 2001） ${ }^{4)}$ 等を参照し、また現地踏査を踏まえて調 査の内容を決めた。調查の内容は、現在園内に分布する 棟瓦彫刻の名称 分布の場所、棟瓦彫刻紋様の意味合い とその寸法である。最後に現存する 645 ヶ所の棟瓦䧓刻 を表-1のとおりまとめた。

\section{4. 匵和園における棟瓦彫刻の調査}

（1）棟瓦彫刻の分布

頣和園の棟瓦彫刻は中国庭園の中で最も多いと言われ、 園内の至る場所に配置された棟瓦彫刻は 1300 ヶ所に及 び、その内保存状態良い645 ヶ所煉瓦彫刻を表一1の通 りまとめた。頣和園の棟瓦彫刻は万寿山の前山（南側） に多く分布され、30 ヶ所に集中し、その内、最も多く分 布している場所は万寿山の前山（南側）の中心部にある 「排雲殿」と「小蘇州街」で、それぞれ 53 ケ所あり全 体の各 8.2\%を占めている。その次は、宜芸館の 51 ヶ所 (7. $9 \%)$ 、玉瀾堂の 43 ヶ所 $(6.7 \%)$ 、楽寿堂の 40 ヶ所 (6. 2\%) 、徳和園の 39 ヶ所 (6.0\%) 、清華軒の 36 ヶ所 (5.6\%) 、四大部洲の 32 ヶ所 $(5.0 \%)$ 、齋清軒の 31 ヶ 所 (4.8\%)、文昌閣の 30 ヶ所 (4.7\%) などであり、全体 の6割 (63.3\%) を超えた。棟瓦彫刻は園林建築様式と庭 園空間との調和を追求すると同時に、その場所で使われ る彫刻装飾の度合いは空間の雰囲気によって決められ、 棟瓦彫刻使用のバランスを全体的に考慮している。

（2）棟瓦彫刻の使われた場所

匵和園での棟瓦彫刻の使われ方にも大きな特徽がある。 それはつまり園内の彫刻装飾の大部分が建築の骨組に組 み込まれていて、宝頂、軒板支えなどは、内部構造の保 護にもなり、また、建築そのものの装飾を美しくする役 割をも果たしていると同時に、その場所にある庭園空間 の表現にも大きな影響を与えている。頣和園の棟瓦䧓刻 の使われた場所は計 15 種であり (表一1 とその注参照)、 その内湿気や高温な空気を柱の周辺に通寸ため、建築基 礎外壁にある「風透し」は557 ヶ所で全体の86\%に及び、 最も多く使われた場所と言え、全園の至るところにすべ て分布されている。その次は、扶手墻（手摺塀） $5 \%$ 、花 池 (花壇) $2 \%$ 、宝頂（皇帝のいる部屋の屋根）1.86\%、花 盤棟瓦（表壁に使う装飾棟瓦）1.7\%となり、全体の 1 割 しか占められていない。その他は掛檐板（軒下支え）の
4 ヶ所、花板（かんおけを造る最上の板）の 3 ヶ所、門 楣 (戸口の上方にある横木) の 3 ヶ所、欄板（かんらん の板）の 2 ヶ所、影壁（門から入った正面にある壁面） の 2 ヶ所、背飾（屋根飾り）の 2 ヶ所、また、望柱（門 前の高い柱）、山花（伝統的家屋両側面の高、壁）、門 券 (門の両側の下部突き出し)、墙垛 (突き出しの部分) はそれぞれ 1 ヶ所づつしか分布していないことが分かっ た。頣和園の庭園空間の表現と特徽は園のそれぞれの場 所にある園林建築の「風透し」の煉瓦彫刻を通して、そ の場所が持つ東洋文化に特有な奥深い空間イメージをも う一つ側面から反映させている。

\section{（3）棟瓦彫刻の紋様（図案）種類}

棟瓦彫刻は一種の独特な装飾芸術として、その図案の 内容やテーマは、もちろん皇家を中心に皇家の好みによ って決められる。頣和園における棟瓦彫刻の紋様は 83 種に及び、主に草花、動物、幾何学図案とその組合せ等 が中心となっている（表一1参照）。その内、最も多い 図案は菊 (長寿) の 200 ケ所で全体の $31.0 \%$ に達してい る。その次は、蓮の花（清廉さ）の81 ヶ所 (12.6\%)、 万寿菊（長寿）の 74 ヶ所 (11.5\%)、牡丹（富貴）の 67 ヶ所 $(10.4 \%)$ 、桃の花 (春) の 43 ヶ所 $(6.7 \%)$ 、巻草 (永遠に続く) の 27 ヶ所 $(4.2 \%)$ 、蘭 ( 格高尚) の 14 ヶ所 (2.2\%) などであり、これらを合計すると全体の ほぼ8割に及ぶ。その他、八吉祥の魚 (堅固、活発、幸 福、魔除け）や陰八仙人の漂篎（仙人来臨、喜賀吉祥） や菱の花（国家泰平、国民平安）などがある。覧和園は 清の時代の皇帝が物質的生活と精神的文明の高度な調和 を追求してできた庭園で、その建築方式には清の時代の 規範制度、宗教儀礼及び風俗習慣が反映されている。

（4）棟瓦彫刻の寸法

匵和園にある煉瓦彫刻の形は宝頂以外すべて長方形で ある。その寸法は 115 190×158～240 mm が大半である。 その内、最も多く使われている棟瓦の寸法は $125 \times 158$ 〜235mm の 101 ヶ所で全体の 15.7\%を占めている。その次 は、126×157〜240 $\mathrm{mm}$ の 53 ヶ所 (8. $2 \%) 、 127 \times 157 \sim 263 \mathrm{~mm}$ の 49 ヶ所 $(7.6 \%) 、 140 \times 170 \sim 234 \mathrm{~mm}$ の 37 ヶ所 $(5.7 \%)$ である。また、 $133 \times 170 〜 180 \mathrm{~mm}$ と $132 \times 170 \sim 222 \mathrm{~mm}$ と 128×158〜240mmの3 寸法の棟瓦彫刻はそれぞれ30 ケ所 で使われ、5.1\%にあたる。以上の5寸法は全体の5割を 超えた。覧和園の中で、最も寸法の大きい棟瓦彫刻は仁 
寿殿にある竜（竜が子を呼ぶ）の影壁（3150×2680mm） である。棟瓦䧓刻の寸法は基本的煉瓦の寸法と一致する ことが多いが、大型棟瓦䧓刻を製作する時には、いくつ かの部分に分けて彫る必要があり、各部分でもいくつも の棟瓦を慗ぎあわせて使わなければならない。

\section{5. 頣和園における棟瓦彫刻の考察}

（1）棟瓦彫刻の庭園空間

頣和園は皇家庭園の最も代表的な逸品で、園林建築様 式と空間との全体的調和を追求している点が大きな特徵 の一つである。従って、庭園のなかで使われる彫刻装飾 の度合いは園林建築空間の雲囲気によって決められ、棟 瓦彫刻使用のバランスを全体的に考慮し、皇室の寛容さ と力強さを際立たせるために風通し、手摺塀装飾、軒下 支え及び宝頂には棟瓦䧓刻がよく使われ、それ以外の城 壁の突き出しなどにはあまり棟瓦彫刻は使われていない。 頣和園での㤓瓦彫刻の使われ方にも大きな特徵がある。 それはつまり園内の彫刻装飾の大部分が建築の骨組みに 組み込まれていて、建築の骨組みの必要不可欠な一部で あり、部品であり、と同時に装飾でもある。宝頂、軒下 支えなどは、内部構造の保護にもなり、園林建築そのも のを美しくする役割をも果たしている。

\section{（2）煉瓦彫刻の紋様（図案）}

頣和園の棟瓦彫刻装飾紋様は、伝統的な吉祥図案を基 にして、皇室御用職人によって繰り返し研究され、実験 されたのちに完成した法式化紋様で、中国の伝統的な棟 瓦彫刻紋様の逸品である。それには秩序化、抽象化、誇 張化、簡潔化、豊富化、象徵化、寓意化などの特徵が見 られる (図一1参照)。秩序化とは、紋様の図案の中で の配列が一定の格式によって行われ、任意的、不一致な、 混乱した状態ではないということである。抽象化とは、 実存の形をある種の符号及び非形象的紋様に置き換える という意味である。誇張化とは形象の本質的な特徽ある いは重要な細部を拡大強調することである。そして簡潔 化とは自然形象の重要でない部分及び余分な細部を省略 することである。所謂豊富化というのは形式美の法則に 従い形体にない部分をさらに付け加えることによって膨 らませることである。また象徴化とは、形象そのものを ある概念のシンボルになるようにすることで、寓意化と は、形象に人々の望むところの意味を含ませるようにす ることを意味する。図一1からも分かるように、頣和園
の棟瓦雕刻の作品は、中国の伝統的紋様の法式化創作法 則の集大成と言えよう。法式化した紋様は頣和園の煉瓦 彫刻の装飾性をさらに高めた。簡潔さで豊富さを表現す る、それは芸術的豊富さである。

（3）棟瓦彫刻の技法

棟瓦彫刻をつくるには高品質の煉瓦が必要である。臨 和園にはこのような作りの精緻華美の棟瓦彫刻が使われ ているのは、皇室が品質の高い棟瓦を入手できることと 密接に関係している。棟瓦彫刻の製作過程はまず彫刻し ようとする棟瓦を削り磨き、“画”（下絵）を描いてか ら“耕”(線彫り)、“釘穴”（穴あけ）“蹠打”（地 打ち）、“打点” (点打ち) などいくつものプロセスが 必要である。“画” は棟瓦彫刻の基礎である。一般的に は各層の製作においては彫るごと、削るごとに新たに下 絵を描かなければならない。“耕”は鳌や槌を使って、 下絵のラインに沿って細かく浅く溝を彫り出す。“耕” した棟瓦の “活” (残寸部分) 以外のところを全部削り 落してしまうというのは “釷穴”である。紋様が複雑で あればあるほど、“釗”の回数が増える。“蹠打”はそ の紋様の内部を彫ることである。これが完成すれば、図 案の基本デザインがほぼ決まり、紋様内容のイメージが 大体出来上げって来る。彫りの出来映えは精緻秀麗であ るかどうか、立体効果は鮮明であるかどうかは、かなり この仕事のできによって決まる。彫るときはそれぞれの 情況を考慮しつつ、作品の力強さ洗練さを追求し、味わ い深い “刀味美”を出す。さらに棟瓦の上にもう一つ棟 瓦を重ねて媻ぐことによって立体感を出す。また、局部 で簡単な透き彫りを用いて、立体感を出すもので、花彫 りの中での草花の枝や鳥獣の足の処理に使われる。煉瓦 彫刻の技法からその芸術性が反映されている。

（4）棟瓦䧓刻の継承

棟瓦彫刻は中国古代の科学技術の産物で、また古代文 化芸術の成果でもある。現代の加工手段と技術を用いれ ば、サイズの揃った色彩豊かな細やかで加工しやすい“現 代棟瓦材”を作ることができる。この素晴らしい伝統的 技術を消化し、継承し、発展させることにより、民族的 特色を強め、芸術的品格を高め、棟瓦彫刻紋様は、誇張 変形にせよ、豊满華麗にせよ、物事本来の美と、人間が 芸術加工を加える時の意識美とが融合して出来上がった ものであって、特定の時代精神を象徴する典型的な紋様 
となったわけである。これらの㤓瓦彫刻にはある程度そ の時代と支配階級の烙印が刻み込まれてはいるが、歴史 の角度と文化の角度のいずれから見ても、民族精神の輝 き老放っており、中国古代の職人の警くべき創造力と優 れた才気を見せている。ゆえに、堀り下げて研究し、こ の素晴らしい伝統的文化遺産を継承し、弘揚す心゙きであ ろう。また煉瓦彫刻からみた庭園空間の特徵を今後も積 み重䄈て研究していきたい。

\section{参考文献}

1）北京市園林局頣和園管理処（2000）：覧和園建園 250 周年記念論文集 : 五州伝播出版社.

2）任莅棣・高木真人・仙田満（2005）：中国の皇家 庭園の廊的空間における利用者の滞留特性に関 する研究：ランドスケープ研究 68(5)，421-424. 祝丹・蓑茂寿太郎（2005）：北京・臨和園の敷地 計画に見る歴史的積層性の研究 68(5)，425-428.
章俊華（2000）：中国皇家庭園と私家庭園の「屋 宇」による空閒構成の特徵とその比較について： ランドスクープ研究 63(5)，399-402。章俊華 （1999）：中国皇家庭園賢和園における「扁額 からみた空間構成の特徴について:ランドスケー プ研究 62(5)，761 764. 沈悦・熊谷洋一・下村 彰男・小野良平（1997）：北京覧和園における景 観形成と西湖景観の影響について : ランドスケー プ研究 60 (5)，577〜582.など。

3）頣和園設計室、頣和園文化研究室（2000）：覧和 園礌彫芸術 : 北京燕山出版社。

4）下山重丸（1990）: 中国造園関連文化史 : 同朋舎, 6-16, 26-51. 橋川時雄（1970）：明・計無否の「園 治」とその解説: 渡辺書店, 41-44. 王立導 (1987)： 吉祥図案 : 朝花美術出版社、葉応燧ら（2001）中 華吉祥図中国旅游出版社など。

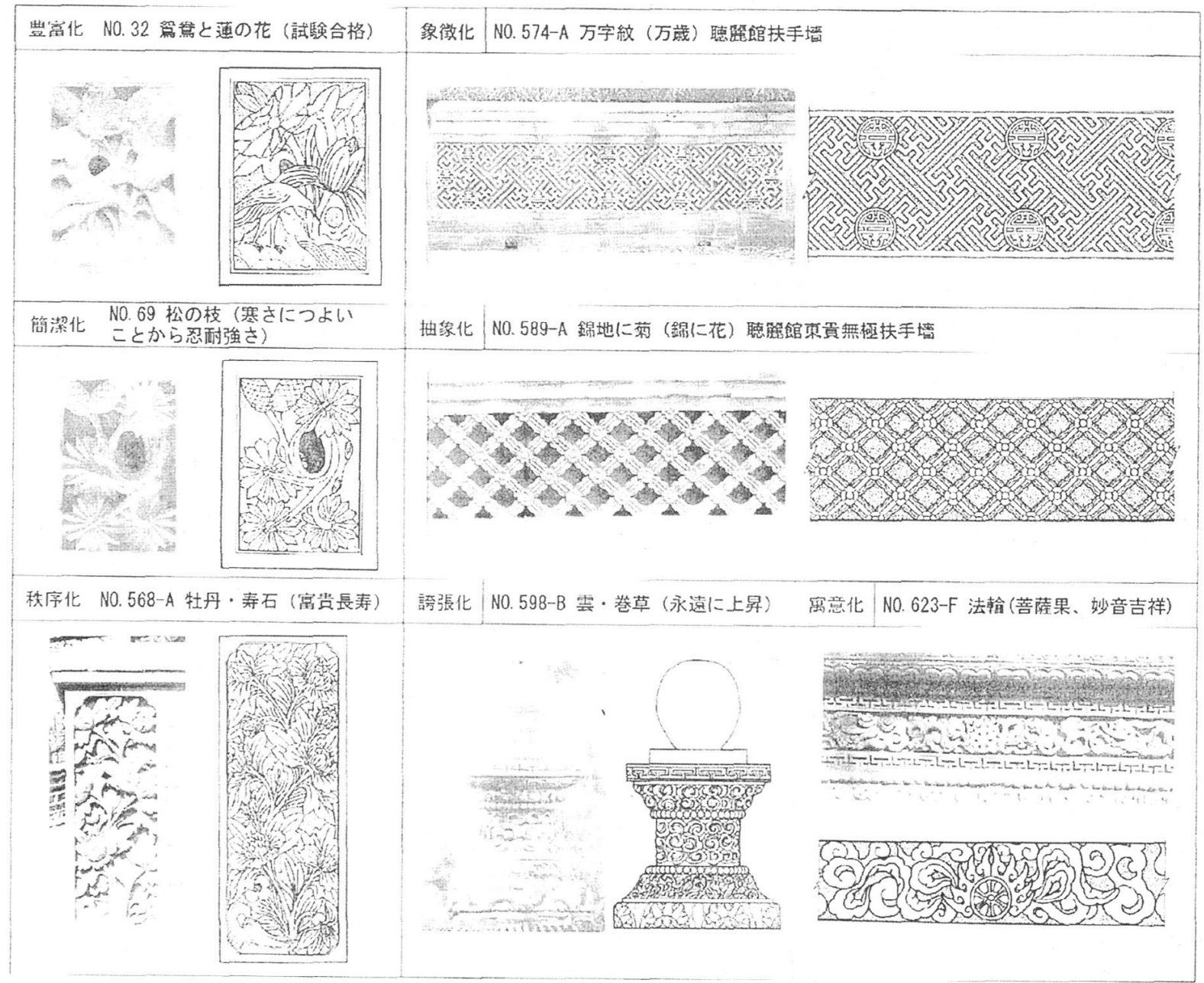

図一1 願和園における棟瓦彫刻の紋様（図案） 


\begin{tabular}{|c|c|c|c|c|c|c|c|c|c|}
\hline \multicolumn{10}{|c|}{ 表一1 碩和園における棟瓦彫刻の分布と概要（その1） } \\
\hline No. & 紋様名 & 埸所 & \begin{tabular}{|c|} 
意味 \\
\end{tabular} & 寸法(nm) & No. & 紋橧名 & 埸所 & 意味 & 寸法 \\
\hline 1 & 陰八仙人敖䇤 & 東宮門南照 & 仙人来臨残驾吉样 & $127 \times 190$ & 82 & 速の花 & 玉洞門外西側南 & 清错さ & $155 \times 127$ \\
\hline 2 & 茶花 & 東宮門腩朝房 & 禁 & $128 \times 240$ & 83 & 菊 & 霞芬室舒監東溉1 & 莀毒 & $127 \times 180$ \\
\hline 3 & 菊 & 東宮門㑲朝原 & 舆森 & $137 \times 240$ & 84 & 䓵 & 露芬室南虽東側2 & 脣素 & $125 \times 185$ \\
\hline 4 & 菊 & 東宮門献朝原 & 長慗 & $125 \times 197$ & 85 & 牡丹 & 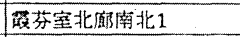 & 代及䈏费 & $125 \times 175$ \\
\hline 5 & 海等 & 東宮門南朝房 & 湡堂(多子多孫) & $125 \times 197$ & 86 & 闌 & 臀芬室北衩南北2 & 人格高尚 & $128 \times 176$ \\
\hline 6 & 获 & 北九聊西側 & 長毒 & $125 \times 165$ & 87 & 速の花 & 霞芬室北漧湳北3 & 清撞さ & $120 \times 175$ \\
\hline 7 & 获 & 北九的東照 & 長费 & $125 \times 180$ & 88 & 箱 & 陆芬室北激南北4 & 長奉 & $128 \times 175$ \\
\hline 8 & 㸁の花 & 北九卿東側 & 清廉さ & $125 \times 165$ & 89 & 万奜菻 & 雪香塮南壁西側1 & 脣萠 & $128 \times 190$ \\
\hline 9 & 牡丹 & 南九㗦東壁 & 代々富费 & $125 \times 174$ & 90 & 药 & 雪香榭南照西側2 & 長筹 & $128 \times 190$ \\
\hline 10 & 梅の花 & 仁陦南殿東墪 & 忍㑯强さ & $125 \times 190$ & 91 & 莎薇の花 & 䔉香謝北照西側 & 花の王妃 & $125 \times 175$ \\
\hline 11 & 八吉祥の瓶 & 仁踭北貶西照 & 成功と名举と寒利 & $125 \times 190$ & 92 & 获 & 薄香塮北唧南北 & 長奉 & $125 \times 172$ \\
\hline 12 & 八吉样の魚 & 仁传北殿西照 & 堅固活発、筑除け & $125 \times 190$ & 93 & 昰芝 & 玉闠堂西暲北側 & 如意 & $126 \times 174$ \\
\hline 13 & 八吉样の数 & 仁荚北殿東照 & 仏法の輪 生命が末亦い & $125 \times 191$ & 94 & 盎芝 & 玉瀾堂西照中央 & 如意 & $126 \times 197$ \\
\hline 14 & 轮丹 & 仁毒南殿南側 & 代々富贵 & $127 \times 154$ & 95 & 牡丹 & 玉減堂東整南㑡 & 代々䈏贵 & $126 \times 195$ \\
\hline 15 & 速の花 & 仁竹殿南側 & 清廉さ & $126 \times 158$ & 96 & 获 & 夕佳楼湳激南北 & 長拝 & $125 \times 172$ \\
\hline 16 & 牡丹 & 仁彂殿障照 & 代々富蛽 & $160 \times 230$ & 97 & 遇の花 & 夕佳楼北璧西側 & 清廉さ & $128 \times 190$ \\
\hline 17 & 菊 & 仁実殿南照 & 長寿 & $160 \times 230$ & 98 & 菊 & 夕佳搂南照西側 & 長唪 & $128 \times 190$ \\
\hline 18 & 牡丹 & 仁敖殿西侧 & 代々䈏费 & $160 \times 230$ & 99 & 王閶 & 夕佳楼北照西側 & 清さと春の到来 & $125 \times 190$ \\
\hline 19 & 菊 & 仁彂殿西億 & 長寿 & $143 \times 241$ & 100 & 䢖の花 & 夕佳楼北㑡南北1 & 清棌さ & $125 \times 190$ \\
\hline 20 & 牡丹 & 仁竹毁西照 & 代々富素 & $163 \times 230$ & 101 & 诫 & 東穿堂南壁東側 & 長毒 & $126 \times 158$ \\
\hline 21 & 莸 & 仁盽殿西㖕 & 長䍹 & $143 \times 230$ & 102 & 获之鳥 & 夕佳楼北廊俑北2 & 一家を举げての喜び & $126 \times 168$ \\
\hline 22 & 栉 & 仁奉殿後潪西 & 長棒 & $143 \times 235$ & 103 & 轮丹 & 宜芸馆東源車西 1 & 代々管贵 & $127 \times 160$ \\
\hline 23 & 茂 & 仁奈殿二階检 & 長奉 & $160 \times 226$ & 104 & 遇の花 & 宜芸馆赖澶東西2 & 清廉さ & $127 \times 158$ \\
\hline 24 & 荡 & 仁陦殿二階桻 & 長寿 & $160 \times 227$ & 105 & 運の花 & 宜芸官官東䃇香西3 & 湋粟さ & $126 \times 161$ \\
\hline 25 & 菊 & 仁踭殿二階譛 & 長奉 & $142 \times 236$ & 106 & 蚍の花 & 宜芸馆東䂙東西4 & 清寀さ & $126 \times 160$ \\
\hline 26 & 诫 & 仁挈殿二階北 & 長毒 & $142 \times 236$ & 107 & 万契菊 & 宣芸馆埬硬東西5 & 長邫 & $126 \times 158$ \\
\hline 27 & 薄 & 仁契镫二階北 & 長奉 & $142 \times 236$ & 108 & 㳦 & 宜芸館西儌東西1 & 長阷 & $125 \times 160$ \\
\hline 28 & 轮丹 & 仁奉㩔二階北 & 代々富贵 & $142 \times 236$ & 109 & 万毒㖑 & 宜芸館西䂙東西2 & 脣奉 & $125 \times 158$ \\
\hline 29 & 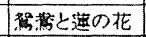 & 贀楽殿内庭東 & 恜験合格 & $165 \times 240$ & 110 & 牡丹 & 宜芸馆西䂙東西3 & 代々富贵 & $125 \times 161$ \\
\hline 30 & 菜 & 頭楽㺿内庭東 & 長奉 & $164 \times 240$ & 111 & 茧の花 & 宜芸馆西䂙東西 4 & 清廉さ & $128 \times 158$ \\
\hline 31 & 菊 & 䫝楽㩔内庭東 & 長寿 & $164 \times 240$ & 112 & 烈 & 宜芸馆西研南北1 & 人格高尚 & $127 \times 160$ \\
\hline 32 & 䇥船と速の花 & 頋潹殹内庭東 & 碔致合格 & $164 \times 240$ & 113 & 速の花・䒤满 & 宜芸館西碓俑北2 & 根が堅固で繁盛する & $126 \times 160$ \\
\hline 33 & 㳦 & 庭望堂内庭東 1 & 長寿 & $164 \times 240$ & 114 & 胡轧 & 道存省北暲東側 & 三元及第 & $127 \times 160$ \\
\hline 34 & 荡 & 受嗐堂内庭東2 & 長奉 & $164 \times 240$ & 115 & 松の枝 & 道存蒜東暲西側 & 寒さにつ上いにとから忍耐強さ & $130 \times 194$ \\
\hline 35 & 荡 & 愛善堂内庭東3 & 長巻 & $164 \times 240$ & 116 & 第 & 道存斎北側 & 長唪 & $127 \times 160$ \\
\hline 36 & 菻 & 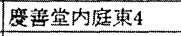 & 長奉 & $165 \times 236$ & 117 & 㳦 & 道存窈南側 & 長奉 & $127 \times 160$ \\
\hline 37 & 桃の花 & 德和圆西側 & 春 & $133 \times 172$ & 118 & 䢖の花 & 道存㟢南的南北 1 & 哖寀さ & $127 \times 160$ \\
\hline 38 & 葋 & 德和固西側 & 長素 & $133 \times 172$ & 119 & 遇の花 & 道存碢南酣南北2 & 清寀さ & $127 \times 160$ \\
\hline 39 & 葋 & 德和固東側 & 長絜 & $137 \times 177$ & 120 & 菊 & 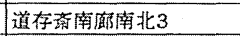 & 長契 & $127 \times 160$ \\
\hline 40 & 菊 & 德和固的庭 & 長范 & $135 \times 170$ & 121 & 速の花 & 道存葫南鸱南北 4 & 清鿬さ & $127 \times 160$ \\
\hline 41 & 落 & 德和固剖庭 & 長奉 & $133 \times 178$ & 122 & 葡 & 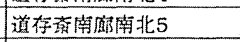 & 唇棒 & $124 \times 160$ \\
\hline 42 & 鶧 & 德和固戲楼東 & 長寿 & $157 \times 235$ & 123 & 狦䖝 & 道存滰東照北側 & 子孫万代 & $128 \times 190$ \\
\hline 43 & 桃の花 & 德和圆虥搂束 & 春 & $158 \times 235$ & 124 & 荡 & 宜芸館西暲北側1 & 長軼 & $125 \times 190$ \\
\hline 44 & 葋 & 德和固處楼西 1 & 長絜 & $158 \times 233$ & 125 & 获 & 宜芸館西照北侧2 & 長奉 & $125 \times 190$ \\
\hline 45 & 㳦 & 德和圆戱楼西2 & 長寿 & $158 \times 233$ & 126 & 配篗 & 道存楛東北照東側! & 子孫万代 & $125 \times 158$ \\
\hline 46 & 蚍の花 & 䫝楽殿前庭西 & 清赛さ & $126 \times 171$ & 127 & 萢 & 宣芸館東北照北側1 & 長寿 & $128 \times 160$ \\
\hline 47 & 菊 & 德和固戯楼西 & 長毒 & $156 \times 235$ & 128 & 梅の花 & 宜芸㿟東北照北側2 & 忍耐強さ & $128 \times 158$ \\
\hline 48 & 聎の花 & 欧面殿㷙庭西 & 春 & $131 \times 171$ & 129 & 万蛪药 & 宜芸馆東北㢈西側 & 長寿 & $127 \times 160$ \\
\hline 49 & 莸 & 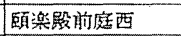 & 長率 & $130 \times 170$ & 130 & 䧟の花 & 宜芸館西北的北侧 1 & 清囌さ & $127 \times 160$ \\
\hline 50 & 桃の花 & 頭楽殿前庭西1 & 秦 & $132 \times 170$ & 131 & 万坓获 & 宜芸館西北㟲北侧2 & 長奉 & $127 \times 160$ \\
\hline 51 & 桃の花 & 䫄楽殿前庭西2 & 春 & $132 \times 170$ & 132 & 速の花 & 宜芸黏北阴東照北側 & 消䖽さ & $131 \times 172$ \\
\hline 52 & 桃の花 & 頤楽殿前庭西3 & 春 & $132 \times 170$ & 133 & 牡丹 & 宜芸馆北門西暟北側 & 代々菑贵 & $163 \times 236$ \\
\hline 53 & 海棠 & 賢楽殿前庭西 & 落堂(多子多係) & $132 \times 170$ & 134 & 牡丹 & 宜芸館北門西垶伞側 & 代々富贵 & $164 \times 236$ \\
\hline 54 & 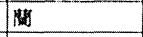 & 酘楽殿前庭西 & 人格高尚 & $124 \times 191$ & 135 & 海棠 & 宜芸館北阴轓砶柬西 1 & 满堂(多子多孫) & $190 \times 236$ \\
\hline 55 & せんじけ芽 & 頋楽㩔前庭東 & 長誨 & $130 \times 170$ & 136 & 监芝 & 宜芸館北阳東被東西2 & 如意 & $124 \times 186$ \\
\hline 56 & 菞 & 頤楽殹前庭東1 & 長踭 & $138 \times 178$ & 137 & 速の花·苩嗬 & 宣芸館北門呠敫東西3 & 根が堅固で繁盛する & $132 \times 172$ \\
\hline 57 & 蔡 & 烦楽殿前庭東2 & 長奉 & $138 \times 178$ & 138 & 轮丹 & 宜芸㿟北阴西激東西 1 & 代々富贵 & $137 \times 175$ \\
\hline 58 & 菊 & 頣楽殿前庭東3 & 長传 & $138 \times 178$ & 139 & 蓓微の花 & 宜芸館北門西确東西2 & 花の王妃 & $132 \times 170$ \\
\hline 59 & 䅉の花 & 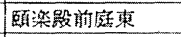 & 清廉さ & $139 \times 177$ & 140 & 万彂茯 & 宜芸馆北門西廊宣西 3 & 長寿 & $135 \times 175$ \\
\hline 60 & 䔎の代 & 頋楽殿渞庭束 & 清实さ & $138 \times 178$ & 141 & 万传蔡 & 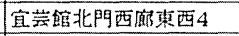 & 脣政 & $137 \times 173$ \\
\hline 61 & 桃の花 & 頭楽期肳庭東1 & 秦 & $164 \times 240$ & 142 & 万传萢 & 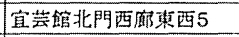 & 長费 & $135 \times 178$ \\
\hline 62 & 桃の花 & 頭楽殿前庭東2 & 鋗 & $164 \times 240$ & 143 & 万传菞 & 宜芸館西北阴南砶南北1 & 長奉 & $132 \times 172$ \\
\hline 63 & 菊 & 頍楽殿西㡠 & 長㹃 & $173 \times 240$ & 144 & 荡 & 宜芸馆西北門南酣南北2 & 长陦 & $132 \times 170$ \\
\hline 64 & 挑の花 & 䨘鄯堂内庭西 & 登 & $128 \times 158$ & 145 & 蚍の花 & 宣芸馆西北門南的南北3 & 清廉さ & $130 \times 168$ \\
\hline 65 & 牡丹 & 頤楽毁東照 & 代々富费 & $164 \times 240$ & 146 & 梅の花 & 宣芸館西北門谳酥南北4 & 忍矿強さ & $132 \times 172$ \\
\hline 66 & 蓬の花 & 度鄯堂内庭西 & 清寀さ & $128 \times 158$ & 147 & 连の花·营蒲 & 宜芸館西北門南郁南北5 & 根が堅固で繁盛する & $132 \times 172$ \\
\hline 67 & 徃丹 & 王满門東 & 代々富費 & $126 \times 170$ & 148 & 䔁 & 宜芸館西北門北碚南北1 & 長奉 & $135 \times 177$ \\
\hline 68 & 莲の花 & 玉娚阳外束側 & 清群さ & $127 \times 173$ & 149 & 葋 & 宜芸館西北門北嫄南北2 & 恶清 & $138 \times 178$ \\
\hline 69 & 松の技 & 玉洞門東酣の南1 & 寒さにっ上いとから忍酎強さ & $125 \times 175$ & 150 & 桃の花 & 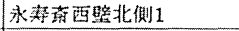 & 春 & $130 \times 190$ \\
\hline 70 & 松の技 & 玉佩門東确の南2 & 寒さにっ上いにとから忍耐强さ & $128 \times 172$ & 151 & 八吉样の进の花 & 永㭋察西暲北側2 & 清淡さ & $130 \times 195$ \\
\hline 71 & 牡丹 & 玉測門東滇の南3 & 代夕富贵 & $127 \times 193$ & 152 & 葡 & 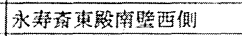 & 镸抟 & $128 \times 170$ \\
\hline 72 & 轮丹 & 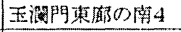 & 代及富筫 & $127 \times 193$ & 153 & 挑の花 & 永毒花東殿北照西側 & 春 & $160 \times 225$ \\
\hline 73 & 万奉获 & 玉澗門東惦の果 1 & 長素 & $126 \times 190$ & 154 & 桃の花 & 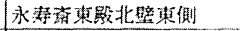 & 稪 & $165 \times 240$ \\
\hline 74 & 碀 & 玉㽚門東矿の東2 & 長素 & $128 \times 172$ & 155 & 速の北 & 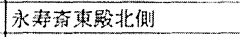 & 清寀さ & $165 \times 240$ \\
\hline 75 & 万奉菊 & 玉減門東碚の東3 & 長素 & $128 \times 172$ & 156 & 遇の花 & 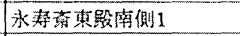 & 清舞さ & $165 \times 240$ \\
\hline 76 & 㳦 & 玉测門東䃇の東 4 & 長寿 & $127 \times 190$ & 157 & 牡丹 & 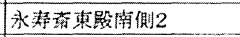 & 代么富贵 & $160 \times 225$ \\
\hline 77 & 万毒符 & 玉濯門西砸の南 1 & 長奉䄅 & $127 \times 170$ & 158 & 万来药 & 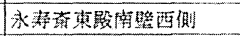 & 長传 & $125 \times 190$ \\
\hline 78 & 牡丹 & 玉浿門西酣の南2 & 代々富费 & $150 \times 180$ & 159 & 万梼菊 & 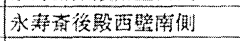 & 严奉 & $130 \times 170$ \\
\hline 79 & 万菶氛 & 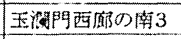 & 長踭 & $127 \times 173$ & 160 & 针丹 & 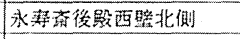 & 代々菑资 & $130 \times 170$ \\
\hline 80 & 㳦 & 玉灌阴西傎の南4 & 舆毒 & $127 \times 173$ & 161 & 速の花 & 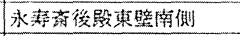 & 潜採さ & $132 \times 170$ \\
\hline 81 & 速の花 & 玉㴓門外西側東西 & 清㝗さ & $127 \times 157$ & 162 & 域 & 水木自親真酸東西 1 & 㗨沄 & $126 \times 157$ \\
\hline
\end{tabular}




\begin{tabular}{|c|c|c|c|c|c|c|c|c|c|}
\hline \multicolumn{10}{|c|}{ 表一1＼cjkstart碩和園における棟瓦彫刻の分布と概要（その2） } \\
\hline No. & 紋様名 & 場所 & 工意昧 & 寸法 & No. & \begin{tabular}{|c|} 
紋樣名 \\
\end{tabular} & 場所 & 意味 & 寸法 \\
\hline 163 & 菊 & 水木自親東配東西2 & 長竹 & $128 \times 158$ & 244 & 荛の花 & 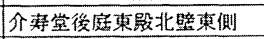 & 清廉さ & $127 \times 160$ \\
\hline 164 & 量の花 & 水木自親東碇東西 3 & 清䌽さ & $128 \times 159$ & 245 & 万英茀 & 介韦堂後庭湧殿西僋 & 長奉 & $125 \times 157$ \\
\hline 165 & 遇の花 & 水木自贑東激東西 4 & 清隤さ & $127 \times 158$ & 246 & 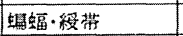 & 排票殿阴西照北側 & 福寿吉样 & $160 \times 230$ \\
\hline 166 & 万坓获 & 水木自親東影東西5 & 長寿 & $126 \times 156$ & 247 & 桃の花 & 排雲殿門西励東西1 & 春 & $132 \times 172$ \\
\hline 167 & 菊 & 水木自親西激束西1 & 長涛 & $132 \times 175$ & 248 & 䄻の花 & 排雴殿阴西源東西 2 & 春 & $132 \times 172$ \\
\hline 168 & 笨 & 水木自親西鄓東西 2 & 長寿 & $133 \times 175$ & 249 & 万传获 & 排犟殿玉華殷南廊南北1 & 長奉 & $127 \times 165$ \\
\hline 169 & 菊 & 水木自親西的東西3 & 長毒 & $133 \times 175$ & 250 & 菊 & 排零殿門西䂙東西1 & 長奉 & $132 \times 172$ \\
\hline 170 & 获 & 水木自親西酣東西 4 & 長寿 & $133 \times 172$ & 251 & 䓶 & 排害殿玉華殷南衩南北2 & 長彗 & $127 \times 165$ \\
\hline 171 & 牡丹 & 水木自親西酣東西5 & 代々富费 & $133 \times 170$ & 252 & 桃の花 & 排雲殿玉華岞南溮南北 3 & 春 & $126 \times 160$ \\
\hline 172 & 10 & 水木自親西酒東西6 & 人格高尚 & $132 \times 170$ & 253 & 八吉样の藍 & 排票殿玉茟殿南側1 & 疬気治瘦 & $126 \times 190$ \\
\hline 173 & 葡 & 水木自親西酣東西7 & 長竹 & $134 \times 170$ & 254 & 八吉祥の速の花 & 排需殿玉華殿南側2 & 清滋さ & $126 \times 190$ \\
\hline 174 & 万陦苯 & 水木自親西䂙東西8 & 長瑃 & $132 \times 170$ & 255 & 遥の花 & 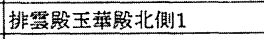 & 清寀さ & $126 \times 190$ \\
\hline 175 & 紫 & 水木自親東璧南側 & 長獉 & $128 \times 190$ & 256 & 㓌八仙人の木魚 & 排雲殿玉華殿北側2 & 仙人来臨、瑊賀吉样 & $126 \times 190$ \\
\hline 176 & 菊 & 水木自親西燱南側 & 長㐩 & $130 \times 190$ & 257 & 䧔八仙人の団局 & 二階芳䂒殿南側1 & 仙人来臨、害賀吉样 & $126 \times 190$ \\
\hline 177 & 菊 & 楽唪堂湖庭東殿北䃥東側 & 長寿 & $127 \times 155$ & 258 & \begin{tabular}{|l|l|l|l|l|} 
花 \\
\end{tabular} & 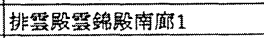 & 清息さ & $132 \times 170$ \\
\hline 178 & 㫫芝 & 楽奉堂前庭東殿南㫢東側 & 如意 & $126 \times 157$ & 259 & 䧔八仙人の陰陽板 & 三階芳輝殿南側 2 & 仙人来醉、喜賀吉样 & $126 \times 190$ \\
\hline 179 & 䔫 & 楽寿堂西殿北廊南北 1 & 長韦 & $132 \times 170$ & 260 & 陰八仙人の宝创 & 二階芳疑殿北側1 & 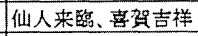 & $126 \times 190$ \\
\hline 180 & 桃の花 & 楽费堂西殿北激南北2 & 春 & $132 \times 172$ & 261 & 隍八仙人の笛 & 二階方䡣殿北側2 & 仙人来臨、喜賀吉样 & $126 \times 190$ \\
\hline 181 & 菊 & 楽寿堂西殿北激南北3 & 長毒 & $132 \times 172$ & 262 & 轮丹 & 三階殿紫殿故郋南北1 & 代々富费 & $133 \times 170$ \\
\hline 182 & 茐 & 楽專堂西殷北激南北4 & 長蔧 & $132 \times 172$ & 263 & 菊 & 二階殿紫钤南㔊南北2 & 長苼 & $126 \times 173$ \\
\hline 183 & 竹 & 楽奉堂西殿北菂南北5 & 若々しい & $132 \times 172$ & 264 & 药 & 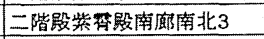 & 長椿 & $130 \times 173$ \\
\hline 184 & 傕の花 & 楽寿堂西殿南垶西側 & 清祭さ & $128 \times 190$ & 265 & 菊 & 二階殿紫碃殿南激南北4 & 長寿 & $170 \times 133$ \\
\hline 185 & 万荴获 & 楽夷堂西殷北燱西側 & 長寿 & $130 \times 190$ & 266 & 柾 & 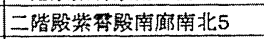 & 長寿 & $133 \times 170$ \\
\hline 186 & 桃の花 & 楽毒堂西殷南廊南北 & 春 & $130 \times 170$ & 267 & 荡 & 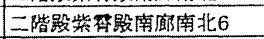 & 長竹 & $133 \times 170$ \\
\hline 187 & 牡丹 & 楽帮堂西殷北側北照の西侧 & 代々富貫 & $140 \times 178$ & 268 & 轮丹 & 二階殿紫期南䂙南北7 & 代々富貴 & $133 \times 170$ \\
\hline 188 & 万寿荇 & 楽唪堂西壁南側 & 長寿 & $128 \times 190$ & 269 & 牡丹 & 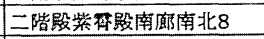 & 代々富费 & $133 \times 170$ \\
\hline 189 & 速の花 & 楽寿堂南殿東璧南側 & 清廉さ & $128 \times 190$ & 270 & 窲 & 二階殿紫秀殿北估南北1 & 長毒 & $133 \times 170$ \\
\hline 190 & 万奉蒘 & 楽涛堂東璧北暲北側 & 長毒 & $127 \times 160$ & 271 & 葡 & 二階殿紫琪北激南北2 & 長寿 & $133 \times 170$ \\
\hline 191 & 菊 & 楽寿堂後庭東激南北 1 & 長坓 & $125 \times 158$ & 272 & 菊 & 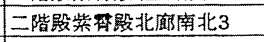 & 長费 & $133 \times 170$ \\
\hline 192 & 荡 & 場仁風西侧西 1 & 長专 & $127 \times 170$ & 273 & 万栔菊 & 三階殿紫䃌段北激南北 4 & 長寿 & $133 \times 170$ \\
\hline 193 & 万奉蒤 & 掦仁風西側西2 & 長奉 & $127 \times 175$ & 274 & 葡 & 二階殿紫脗殷北㵜南北 5 & 長契 & $133 \times 170$ \\
\hline 194 & 慜 & 場仁風東側東 & 長毒 & $127 \times 175$ & 275 & 䄻の花 & 二階殿柴殿北唒南北 6 & 秦 & $133 \times 170$ \\
\hline 195 & 荡 & 楽毒堂後庭東㢈南北2 & 長毒 & $125 \times 158$ & 276 & 藏 & 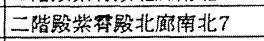 & 長帮 & $133 \times 170$ \\
\hline 196 & 桃の花 & 楽寿堂後庭東廊南北3 & 春 & $125 \times 158$ & 277 & 独 & 二階殿紫破殷北的南北8 & 長牢 & $133 \times 170$ \\
\hline 197 & 海棠 & 楽寿堂後庭東廊南北 4 & 湢堂(多子多孫) & $125 \times 158$ & 278 & 葡 & 二階殿紫票殿北廊南北 9 & 長寿 & $133 \times 170$ \\
\hline 198 & 挑の花 & 楽寿堂後庭東䂙南北5 & 春 & $125 \times 158$ & 279 & 遥の花 & 二階殿紫害殿北㢈南北10 & 清塀さ & $133 \times 170$ \\
\hline 199 & 满 & 楽陦堂後庭東䂙南北6 & 人格高尚 & $125 \times 158$ & 280 & 牡丹 & 三階殿紫殿南側1 & 代々富贵 & $183 \times 230$ \\
\hline 200 & 谒蝠·無 & 楽陦堂後殿西暲北側1 & 福阷吉祥 & $127 \times 175$ & 281 & 牡丹 & 二階殿紫殿南側2 & 代々富贵 & $183 \times 230$ \\
\hline 201 & 获 & 楽寿堂後殿西照北側2 & 長奉 & $127 \times 175$ & 282 & 菊 & 二階殿紫魯殿北側1 & 長寿 & $183 \times 230$ \\
\hline 202 & 速の花 & 邀月門関濻南北1 & 清察さ & $133 \times 170$ & 283 & 荍 & 二階殿紫弯殿北側2 & 長寿 & $183 \times 230$ \\
\hline 203 & 万䞐获 & 邀月門南瑯南北 2 & 長恝 & $132 \times 170$ & 284 & 获 & 德短殿東璧北側 & 長棒 & $126 \times 158$ \\
\hline 204 & 万琫获 & 邀月門哃敫南北 3 & 長奉 & $132 \times 172$ & 285 & 姚の花 & 德知殿西壁北側 & 春 & $165 \times 241$ \\
\hline 205 & 和 & 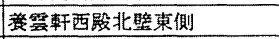 & 長瑃 & $133 \times 173$ & 286 & 葡 & 香海其縁西監南側 & 長寿 & $128 \times 180$ \\
\hline 206 & 整 & 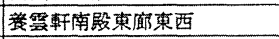 & 長毒 & $135 \times 173$ & 287 & 菊 & 香海真縁東垶南側 & 赛邫 & $132 \times 178$ \\
\hline 207 & 薄 & 無尽意軒門西激東西 1 & 長表 & $127 \times 172$ & 288 & 菊 & 香海真縁西暲北侧 & 長寿 & $124 \times 180$ \\
\hline 208 & 葡 & 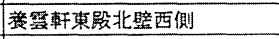 & 長寿 & $133 \times 173$ & 289 & 菊 & 仏香閣欮門西暲南側 & 萇君 & $158 \times 240$ \\
\hline 209 & 巻草 & 巻雲亁北照西側 & 永遠に䌇く & $126 \times 170$ & 290 & 涤 & 仁香閣前門西燱北側 & 長帮 & $160 \times 240$ \\
\hline 210 & 慜 & 荃需軒南殿西㩁東西 & 長奉 & $133 \times 173$ & 291 & 遇の花 & 仏香閣前門東壁偳側 & 清㲅さ & $143 \times 230$ \\
\hline 211 & 巻草 & 意零軒北旺束側 & 水遠に統く & $125 \times 170$ & 292 & 違の花 & 仏香閣後門東暜北側 & 清寀さ & $147 \times 236$ \\
\hline 212 & 虺の花 & 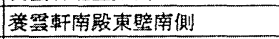 & 清籍さ & $133 \times 170$ & 293 & 海棠 & 仏香閣後門東照南側 & 满堂(多子多孫) & $144 \times 227$ \\
\hline 213 & 类草 & 费霊軒東殿北旺東側 & 永邀に縝く & $125 \times 170$ & 294 & 牡丹 & 仏香閣後門西壁北側 & 代々富贵 & $160 \times 245$ \\
\hline 214 & 萬 & 無尽意軒門西矿東西2 & 清さ & $132 \times 195$ & 295 & 牡丹 & 仏香閣後門西垶南侧 & 代々富貴 & $160 \times 240$ \\
\hline 215 & 菊 & 無尽意軒門西矿東西 3 & 長费 & $132 \times 197$ & 296 & 桃の花 & 西哂巴院南殿西照北側 & 秦 & $165 \times 230$ \\
\hline 216 & 万奉菻 & 無尽意軒門東㰾東西 & 長奉 & $135 \times 191$ & 297 & 䙵芝 & 西哂巴院南殷東暜北侧1 & 如意 & $164 \times 233$ \\
\hline 217 & 遇 & 無尽意軒西殿北側 & 清さ & $133 \times 179$ & 298 & 桃の花 & 西喓巴院献殷西照北側2 & 共 & $165 \times 230$ \\
\hline 218 & 万夷䔓 & 楅限軒西䪖北㑡1 & 長奉 & $126 \times 230$ & 299 & 㳦 & 西㖶巴院南殿西照南側1 & 長幚 & $165 \times 230$ \\
\hline 219 & 蔡 & 福堅軒西缶北側2 & 長邫 & $126 \times 240$ & 300 & 获 & 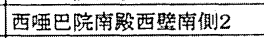 & 長㐩 & $165 \times 230$ \\
\hline 220 & 沙 & 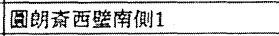 & 長寿 & $140 \times 225$ & 301 & 菊 & 西哂巴院西柞南壁西側 & 長狰 & $132 \times 172$ \\
\hline 221 & 遇の花 & 圆朗窝西照南側2 & 清廉さ & $140 \times 230$ & 302 & 牡丹 & 西㕵巴院西段北噫西側1 & 代々䈏贵 & $135 \times 175$ \\
\hline 222 & 荡 & 圆胉窝東照南側1 & 長奉 & $140 \times 225$ & 303 & 牡丹 & 西㖶巴院西段北照西側2 & 代夕富贵 & $135 \times 175$ \\
\hline 223 & 薄 & 国朗莶東照南側2 & 長彂 & $140 \times 230$ & 304 & 钍丹 & 西理巴院西殿南北1 & 代タ富费 & $135 \times 175$ \\
\hline 224 & 䢖の花 & 圆朗省東虽北側 & 清廉さ & $140 \times 225$ & 305 & 水仙 & 西咞巴院西毁南北2 & 群仙人 & $138 \times 180$ \\
\hline 225 & 万奉宊 & 酷辂台東璧北側 & 長传 & $140 \times 225$ & 306 & 水仙 & 西哽巴院西段南北3 & 群仙人 & $140 \times 180$ \\
\hline 226 & 万奉赋 & 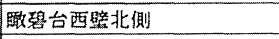 & 長狰 & $140 \times 225$ & 307 & 菊 & 浩萧軒正門東颜東西 1 & 長赫 & $137 \times 175$ \\
\hline 227 & 巻草 & 酷祭台東旺南側1 & 永邀に綐く & $140 \times 225$ & 308 & 荡 & 清華軒正門東的東西 2 & 長狰 & $138 \times 176$ \\
\hline 228 & 菊 & 瞰祭台東燱北側1 & 長奉 & $140 \times 225$ & 309 & 忘れな草 & 清苹軒正門東㢈東西3 & 多子多孫 & $137 \times 175$ \\
\hline 229 & 菞 & 瞰㻌台束毠南側2 & 長㲛 & $140 \times 225$ & 310 & 忘れな草 & 清華草軒正阴涷酣東西 4 & 多子多孫 & $138 \times 176$ \\
\hline 230 & 万寿菊 & 既琴台束照北側2 & 長奉 & $140 \times 225$ & 311 & 慗 & 清萭軒正阴西䂙東西 1 & 長传 & $140 \times 175$ \\
\hline 231 & 万奉䔁 & 介奉堂阴西激東西1 & 長毒 & $126 \times 160$ & 312 & 萬の花 & 清龩軒正門東原東西5 & 清廉さ & $138 \times 176$ \\
\hline 232 & 淢 & 介搸堂門西激束西 2 & 長寿 & $144 \times 190$ & 313 & 荡 & 清㴖軒正門西䂙東西2 & 長传 & $138 \times 175$ \\
\hline 233 & 速の花 & 介佂堂門東菂東西 1 & 清搫さ & $126 \times 189$ & 314 & 进の花 & 清華軒正門西廊東西 3 & 清革さ & $140 \times 175$ \\
\hline 234 & 速の花 & 介赤堂所庭東殿南照東侧 & 清庰さ & $125 \times 190$ & 315 & 速の花 & 清䨣軒正門西激東西 4 & 清绻さ & $138 \times 177$ \\
\hline 235 & 速の花 & 介奉堂門東䂙束西 1 & 清淨さ & $144 \times 190$ & 316 & 万传莥 & 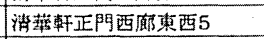 & 長潄 & $137 \times 176$ \\
\hline 236 & 菊 & 介陦堂前庭束殿北确俑北 1 & 長政 & $130 \times 172$ & 317 & 诫 & 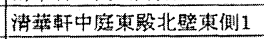 & 長陦 & $140 \times 180$ \\
\hline 237 & 䙵芝 & 介契堂朔庭赖殿北码南北2 & 如意 & $130 \times 175$ & 318 & 蒌 & 清萍軒中庭東殿北照東側2 & 長瑃 & $140 \times 180$ \\
\hline 238 & 轮丹 & 介寿堂前庭東殿北儌南北3 & 代々筧贵 & $130 \times 168$ & 319 & 4 轮丹 & 清䔦軒中庭東殿北㑡 & 代乡露贵 & $140 \times 180$ \\
\hline 239 & 茄枝 & 介毒堂的庭東期北激南北 4 & 三元及第 & $130 \times 168$ & 320 & 牡丹 & 清華亁中庭東殿隔側 & 代么富费 & $140 \times 180$ \\
\hline 240 & 速の托 & 介韧堂後庭南殿西侧東照南 1 & 清獭さ & $125 \times 190$ & 321 & 菊 & 清華亁中庭㮦殷西照北側 & 長整 & $140 \times 178$ \\
\hline 241 & 審の花 & 介寿堂後庭南殿西側東照㑲2 & 清䀧さ & $125 \times 190$ & 322 & 闌 & 清弯亁中庭西毁西側 & 人格高尚 & $164 \times 240$ \\
\hline 242 & 速の花 & 介唪堂後庭南殿西側東壁北1 & 清镂さ & $125 \times 190$ & 323 & 牡丹 & 清莘軒中庭南殿東側 & 代夕管贵 & $140 \times 180$ \\
\hline 243 & 速の花 & 介㭋堂後庭䦽期西側東照北2 & 潜群さ & $125 \times 190$ & 324 & 挑の花 & 雪松策正門西㢈東西 1 & 秦 & $135 \times 190$ \\
\hline
\end{tabular}


表一1 頋和園における棟瓦彫刻の分布と概要（その3）

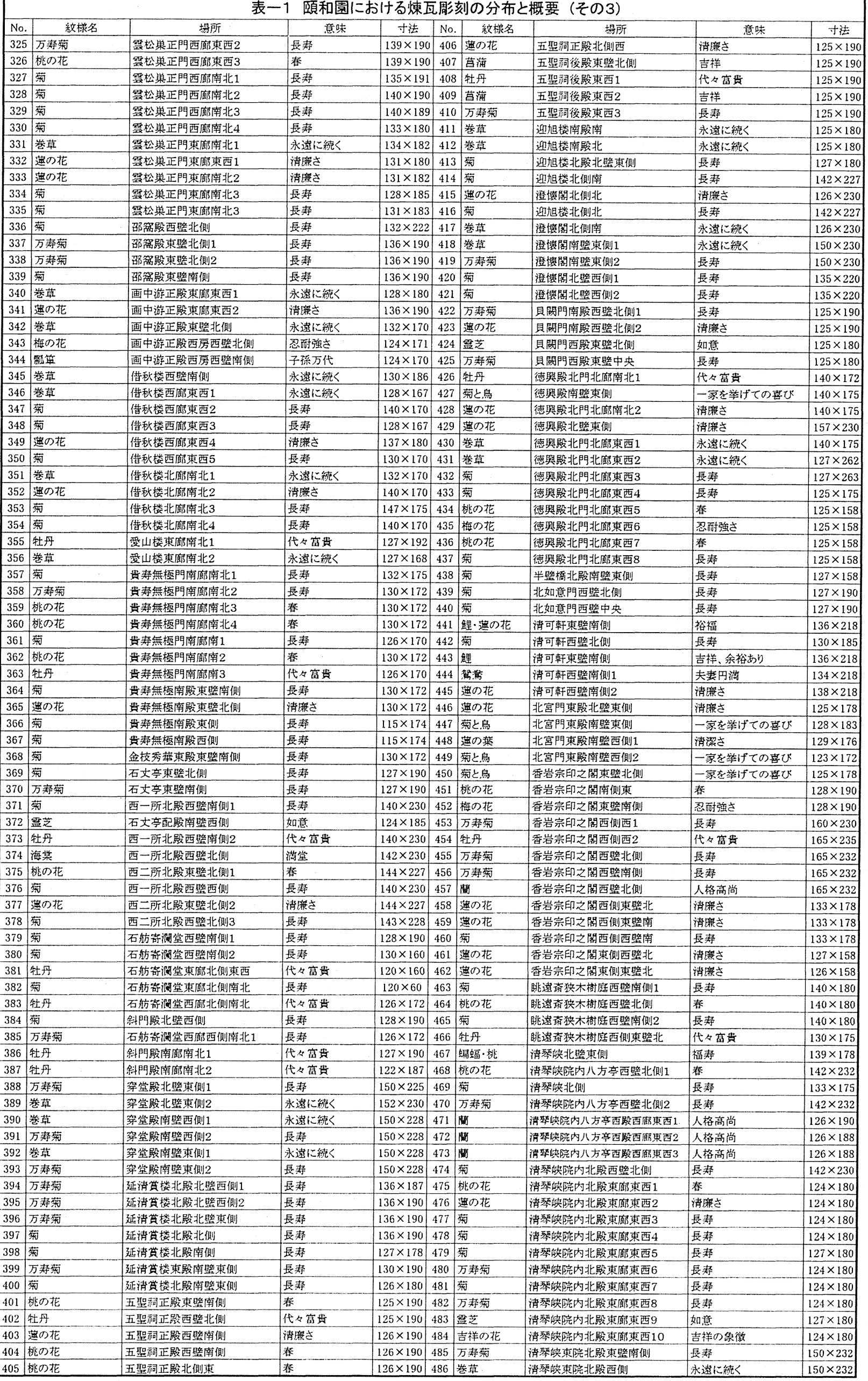




\begin{tabular}{|c|c|c|c|c|c|c|c|c|c|}
\hline \multicolumn{10}{|c|}{ 表－1 頣和園における棟瓦彫刻の分布と概要（その4） } \\
\hline No. & 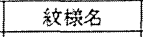 & 場所 & \begin{tabular}{|c|} 
意味 \\
\end{tabular} & 寸法 & No. & 紋様名 & 場所 & 意味 & 寸法 \\
\hline 487 & 万陦蒌 & 清琴岟束院北殿東譬北㑡 & 長䒠 & $150 \times 232$ & $568-\mathrm{A}$ & 牡丹·毒石 & 眺遠常扶手埪正面西南侧南向き & 䈏贵舆奉 & $295 \times 740$ \\
\hline 488 & 牡丹 & 津琴峡東院北殿西照北側 & 代々富贵 & $120 \times 163$ & $569-A$ & 梅·奉石 & 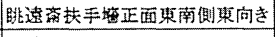 & 春を告げる & $295 \times 740$ \\
\hline 489 & 轮丹 & 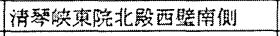 & 代々䈏步 & $120 \times 160$ & $570-\mathrm{A}$ & 苏・帮石 & 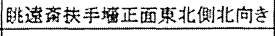 & 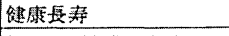 & $295 \times 740$ \\
\hline 490 & 卷草 & 清琴峡東院南殷東壁北側 & 冰透に綍く & $150 \times 233$ & $571-\mathrm{A}$ & 䔎·亘蒲 & 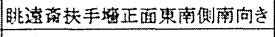 & 根深い，繁盛の意味 & $295 \times 740$ \\
\hline 491 & 万奉犽 & 清琴陕東院鿰殿東㖕中央 & 長寿 & $156 \times 233$ & $572-\mathrm{A}$ & 菞・辈石 & 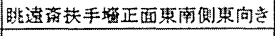 & 踺康舆荴 & $295 \times 740$ \\
\hline 492 & 菊 & 清琴岟東院謿殿西照揇側 & 長奉 & $130 \times 163$ & $573-A$ & 万字紋 & 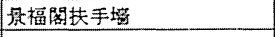 & 万㖪 & $400(\mathrm{H})$ \\
\hline 493 & 轮丹 & 清琴峡東院暔殿東照埇側 & 代々富贵 & $158 \times 233$ & $574-\mathrm{A}$ & 万字紋 & 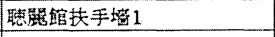 & 万轵 & $570(\mathrm{H})$ \\
\hline 494 & 㖑 & 清矣映東院北殿東照南側 & 長毒 & $175 \times 238$ & $575-\mathrm{A}$ & 鳘甲镍 & 㯖臂館扶手㐭2 & 长求 & $570(\mathrm{H})$ \\
\hline 495 & 桃の花 & 清琴侠東院北殿西照南側 & 共 & $175 \times 238$ & $576-\mathrm{A}$ & 巻草 & 㯖關馆扶手塔 3 & 承遠に綍く & $570(\mathrm{H})$ \\
\hline 496 & 遇の花 & 清琴峡東院南殿北照整側 & 清粠さ & $175 \times 238$ & $577-\mathrm{A}$ & 双筆管 & 写秋軒获手塏 & 長絜 & $530(\mathrm{H})$ \\
\hline 497 & 轮丹 & 清琴峓東院南殿北照西側 & 代么富贯 & $175 \times 238$ & $578-\mathrm{A}$ & 双筆管 & 北宮門外获手境 & 長寿 & $625(\mathrm{H})$ \\
\hline 498 & 闌 & 知春堂南砶南北1 & 人格高尚 & $126 \times 187$ & $579-\mathrm{A}$ & 帮字·舖万字紋 & 諧趣園外茹手境 & 万奉無疆 & $330(\mathrm{H})$ \\
\hline 499 & 万奉犽 & 知春堂南激南北2 & 長寿 & $126 \times 187$ & $580-\mathrm{A}$ & 万字紋 & 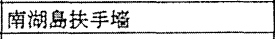 & 万茛 & $520(\mathrm{H})$ \\
\hline 500 & 万奉萢 & 知春堂南䃇南北3 & 長陦 & $126 \times 190$ & $581-\mathrm{A}$ & 万字紋 & 曙新楼扶手諮 1 & 万藏 & $500(\mathrm{H})$ \\
\hline 501 & 速の花 & 知春堂南唒南北 4 & 清革さ & $124 \times 187$ & $582-\mathrm{A}$ & 牡丹 & 曙新楼扶手境 2 & 代々要费 & $480 \times 220$ \\
\hline 502 & 窟の花 & 知春堂南激南北5 & 清䌽さ & $126 \times 187$ & $583-A$ & 牡丹 & 路新楼获手墱3 & 代々富贵 & $480 \times 220$ \\
\hline 503 & 兆の花 & 引䗷西照中央 & 春 & $143 \times 235$ & $584-\mathrm{A}$ & 牡丹 & 曙新楼块手塔 4 & 代々䈏貫 & $480 \times 220$ \\
\hline 504 & 万唪菞 & 引镜東橦北側 & 長寿 & $140 \times 234$ & $585-\mathrm{A}$ & 钍丹 & 曙新楼扶手缹5 & 代々䈏贵 & $480 \times 220$ \\
\hline 505 & 万奉需 & 引鏡東照南側 & 長竹 & $143 \times 227$ & $586-\mathrm{A}$ & 轮丹 & 曙新楼扶手壦6 & 代タ富贵 & $480 \times 220$ \\
\hline 506 & 挑の花 & 引鏡東暲中央 & 春 & $143 \times 225$ & $587-\mathrm{A}$ & 轮丹 & 曙新楼扶手墫7 & 代々笛贯 & $480 \times 220$ \\
\hline 507 & 蓬の花 & 益奉堂外南殿東暜南側 & 清㯒さ & $126 \times 176$ & $588-\mathrm{A}$ & 巻草 & 㯖琶館東贵無極扶手堷 1 & 永遠に繞く & $470(\mathrm{H})$ \\
\hline 508 & 菊 & 益半堂外南殷西房西照南側 & 長奉 & $126 \times 170$ & 589-A & 啥地に菞 & 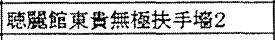 & 啥に花 & $380(\mathrm{H})$ \\
\hline 509 & 葡 & 益专堂外南殷西房西照北側 & 長陦 & $126 \times 173$ & $590-\mathrm{B}$ & 菊と鳥 & 諧趣固知春亭宝頂 & 一家を举げての喜び & - \\
\hline 510 & 桃の花 & 益殹堂門西廊東西 1 & 春 & $125 \times 230$ & $591-B$ & 八吉样の輪 & 琵趣固闌亭宝頂 & 仏法の㫻姻、生命が末氷い & - \\
\hline 511 & 㳦 & 益寿堂門西廊東西2 & 長寿 & $125 \times 230$ & $592-B$ & 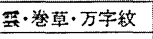 & 諧趣圆小有天宝頂 & 氷遠に繶く·万㐩無疆 & - \\
\hline 512 & 苏 & 益奉堂門西儌東西 3 & 長奉 & $125 \times 230$ & $593-B$ & 菊・万字紋 & 寒心亭宝頂 & 万陦無疆 & - \\
\hline 513 & 菞 & 益寿堂門西激東西 4 & 長寿 & $125 \times 230$ & $594-B$ & 四季如意 & 文昌閣知春亭宝頂 & 年中如意 & - \\
\hline 514 & 万奉㖊 & 益陦堂門西砶東西5 & 長奉 & $125 \times 235$ & $595-\mathrm{B}$ & 四季如意 & 郡箇殿宝頂 & 年中如意 & - \\
\hline 515 & 桃の花 & 益奉堂門西鄉東西6 & 秦 & $125 \times 225$ & $596-\mathrm{B}$ & 八吉样 & 湖光山色共一楼宝頂 & 仙人来臨、吉祥如堭 & - \\
\hline 516 & 万棒域 & 益替堂門東研東西 1 & 長毒 & $125 \times 175$ & $597-B$ & - & 票松笨宝頂 & - & - \\
\hline 517 & 万棒获 & 益絜堂門東滇東西2 & 長藕 & $125 \times 175$ & $598-\mathrm{B}$ & 䨌·巻草 & 石紀小有天宝頂 & 求透に上昇 & - \\
\hline 518 & 竹 & 益奉堂西殷北側 & 若々しい & $125 \times 175$ & $599-B$ & 雲 & 宿䆣售宝項 & 上昇 & - \\
\hline 519 & 荡 & 㭓春桬西側 & 長毒 & $125 \times 230$ & $600-B$ & 四季如意 & 搜雲亭宝項 & 年中如意 & - \\
\hline 520 & 轮丹 & 菘春楿東側 & 代々筒贵 & $125 \times 230$ & $601-B$ & 霥 & 清遥夿宝頂 & 上昇 & - \\
\hline 521 & 㳦 & 菘春藻西殿西側 & 長寿 & $125 \times 230$ & $602-\mathrm{C}$ & 牡丹・奉石 & 德和固北門西照花板 & 長费富贵 & $250 \times 390$ \\
\hline 522 & 遇の花 & 菘春杗東毁東橦北側 & 清革さ & $125 \times 230$ & $603-C$ & 鳥·牡丹 & 清萎軒門的花板 & 富贯白頍まで & $340 \times 380$ \\
\hline 523 & 菞 & 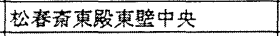 & 長寿 & $125 \times 230$ & $604-C$ & 巻草 & 宿雲格門券 & 永遠に綂く & $340 \times 380$ \\
\hline 524 & 万寿茂 & 松春禁東殿西側 & 長寿 & $125 \times 230$ & $605-\mathrm{C}$ & 卷草 & 紫気東来城関聰垛 & 永遠に綍く & $400(\mathrm{H})$ \\
\hline 525 & 菊 & 松春蒿西殷西璧中央 & 長寿 & $125 \times 230$ & $606-\mathrm{C}$ & 西洋風巻草 & 養雲軒門券(上) & 末永 & $650 \times 650$ \\
\hline 526 & 菊 & 益皋堂外南殿東暲北側 & 長奉 & $126 \times 173$ & $607-\mathrm{C}$ & 西洋風巻草 & 管雲軒門券 (下) & 本永 & $650 \times 650$ \\
\hline 527 & 牡丹 & 耶律楚材湯門南殿北壁西側 & 代々富贵 & $134 \times 172$ & $608-\mathrm{C}$ & 西洋風卷草 & 邆雲軒門相 & 末永 & $380 \times 650$ \\
\hline 528 & 梅の花 & 耶律楚材洞前殿東側 & 忍耐强さ & $130 \times 180$ & $609-C$ & 重草紋 & 石舫背飾1 & 末永 & $650 \times 650$ \\
\hline 529 & 成 & 耶律楚材䄑東殿東側 & 人格高尚 & $125 \times 180$ & $610-C$ & 西洋風巻草 & 石舫背飾2 & 末永 & $650 \times 650$ \\
\hline 530 & 遼の花 & 耶律楚材洞西殿西侧 & 清庵さ & $125 \times 220$ & 611-D & 童 & 仁奉殿影暲 & 竜が子を呼导 & $3150 \times 2680$ \\
\hline 531 & 牡丹 & 文昌閣東南唧南向き東西1 & 代々雷贵 & $125 \times 175$ & $612-D$ & 能 & 石舫山花 & 二能が玉で遊ぶ & $3150 \times 1110$ \\
\hline 532 & 轮丹 & 文昌閣東南酣南向き東西2 & 代々富贵 & $125 \times 175$ & 613-D & 巻草 & 仁表殿影譬 & 永遠に繶く & $1110 \times 3150$ \\
\hline 533 & 轮丹 & 文昌閣東南傎南向き東西3 & 代々䈏费 & $125 \times 175$ & $614-E$ & 姆蝠・犰规万字紋 & 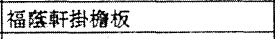 & 楅奉無辺 & $405(\mathrm{H})$ \\
\hline 534 & 轮丹 & 女昌閣柬南酣東向き㑲北1 & 代々富贵 & $125 \times 175$ & $615-E$ & 仏手柑 & 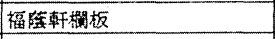 & 楅奉澏堂 & $430(\mathrm{H})$ \\
\hline 535 & 轮丹 & 文昌閣東㑲儌東向き南北2 & 代々富贵 & $125 \times 175$ & $616-\mathrm{E}$ & 蘶上け & 楅蔯軒望板 & 天禄賏福 & $145 \times 480$ \\
\hline 536 & 堨蝠·敕 & 文昜閣東南䂙南向き東西 & 太平、吉样 & $125 \times 175$ & $617-E$ & 毁地に荇 & 石舫二階掛檐板 1 & 锡に花 & $795(\mathrm{H})$ \\
\hline 537 & 牡丹 & 文昌閣東南廊東向き南北3 & 代々富贵 & $125 \times 175$ & $618-E$ & 宝瓶·海棠·牡丹 & 石䄱欄板 & 富邫平安 & $755(\mathrm{H})$ \\
\hline 538 & 八吉祥の榦 & 女昌閣西南倬南向き東西1 & 仏法の输通，生命が末承い & $125 \times 175$ & $619-E$ & 技付き牡丹 & 石舫二階掛檘板 2 & 富贵平安 & $540(\mathrm{H})$ \\
\hline 539 & 遇の花 & 文昌閣西南傎南向き東西 2 & 清啸さ & $125 \times 175$ & $620-E$ & 菞 & 石解花板 & 長奉 & $630(\mathrm{H})$ \\
\hline 540 & 荳の花 & 文昌閣東南激西向き南北1 & 清麻さ & $125 \times 175$ & $621-E$ & 枝付き轮丹 & 石解二階掛钴板 3 & 富费平安 & $540(\mathrm{H})$ \\
\hline 541 & 蓬の葉 & 文昌閣東南部西向き南北2 & 清潔さ & $125 \times 175$ & $622-\mathrm{F}$ & 八吉祥等 & 排雲殿花池1 & 仙人来臨、吉祥如意 & $1340 \times 580$ \\
\hline 542 & 蓕 & 文昌閣涷南的西向き南北3 & 長奉 & $125 \times 175$ & $623-F$ & 法輪 & 排票殿花池2 & 菩限果、妙音吉祥 & $115(\mathrm{H})$ \\
\hline 543 & 万契菻 & 文昌閣東南䂙西向き東西1 & 長整 & $125 \times 175$ & $624-\mathrm{F}$ & 组蝠·宝扇 & 排雯殿花池3 & 八仙人の一人、吉样 & $115(\mathrm{H})$ \\
\hline 544 & 㳦 & 文昌閣東俑㢈西向き東西2 & 長棒 & $125 \times 175$ & $625-\mathrm{F}$ & 宝华 & 排雲殿花池 4 & 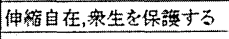 & $115(\mathrm{H})$ \\
\hline 545 & 棫 & 文昌閣東南㢈西向き東西3 & 長奉 & $125 \times 175$ & $626-\mathrm{F}$ & 宝金 & 排需殿花池5 & 伸船自在、乘生を保偊する & $115(\mathrm{H})$ \\
\hline 546 & 进の花 & 女昌閣東南嫏北向き南北1 & 清镂さ & $125 \times 175$ & $627-\mathrm{F}$ & 遇の花 & 排䨝毁花池 6 & 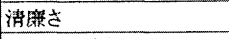 & $115(\mathrm{H})$ \\
\hline 547 & 成 & 文昌閣束㑲矿北向き陵北2 & 人整高尚 & $125 \times 175$ & $628-F$ & 鱹 & 排零殿花池7 & 楅智国茜 & $115(\mathrm{H})$ \\
\hline 548 & 菊 & 文昌閣東南唒西向き東西3 & 長奉 & $125 \times 175$ & $629-\mathrm{F}$ & 金魚 & 排需殿花祀8 & 堅固，活発,幸福，泘除け & $115(\mathrm{H})$ \\
\hline 549 & H & 文昌閣東南碓北向き南北 2 & 人格高尚 & $125 \times 175$ & $630-\mathrm{F}$ & 整目 & 排票殿花池 9 & 全て見通しが明るい & $115(\mathrm{H})$ \\
\hline 550 & 藏 & 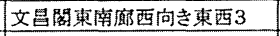 & 長陦 & $125 \times 175$ & $631-\mathrm{F}$ & 馧蝠·花 & 排玨殿花池 10 & 福奉吉样 & $115(\mathrm{H})$ \\
\hline 551 & 八吉样の栄竡 & 文是閣東南矿北向き東西 1 & 苦陵の意味て、、宫样如意 & $125 \times 175$ & $632-\mathrm{F}$ & 螎蝠·如意 & 排害殿花池11 & 橝奉如意 & $115(\mathrm{H})$ \\
\hline 552 & 藏 & 文昌閣東南唒東向き障北1 & 長奉 & $125 \times 175$ & $633-\mathrm{F}$ & 昷蝠·花 & 排雲殿花池12 & 楅對吉样 & $115(\mathrm{H})$ \\
\hline 553 & 万奉犽 & 文昆閣東南酣東向き南北2 & 長奉 & $125 \times 175$ & $634-\mathrm{F}$ & 昷蝠·花 & 排䙵殿花池13 & 楅寿吉祥 & $115(\mathrm{H})$ \\
\hline 554 & 柾と.乌 & 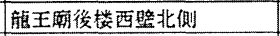 & 一家を举げての琶び & $123 \times 180$ & $635-G$ & 第 & 玉淈門東南花整㶱瓦 & 長寿 & - \\
\hline 555 & 获 & 解王翰後楼北側西晎西 & 長寿 & $125 \times 190$ & $636-\mathrm{G}$ & 轺 & 玉澗門北西花桖煉瓦 & 長毒 & - \\
\hline 556 & 菊 & 酒虚堂宮門東璧北側 & 長陦 & $123 \times 175$ & $637-G$ & 获 & 玉瀾門東北花盤煉瓦 & 長彗 & - \\
\hline 557 & 得 & 能王朝後楼東側南側 & 長寿 & $125 \times 188$ & $638-G$ & 葡 & 玉減堂正殿東揇花整棟瓦 & 長奉 & - \\
\hline $558-\mathrm{A}$ & 丸坓万字紋 & 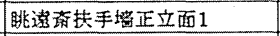 & 万㭋無疆 & $395(\mathrm{H})$ & $639-\mathrm{G}$ & 牡丹 & 玉沺堂正殿西南花盤煉瓦 & 代々筑贵 & - \\
\hline $559-\mathrm{A}$ & 丸㭋万字䋝 & 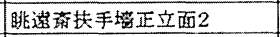 & 万帮無疆 & $395(\mathrm{H})$ & $640-G$ & 菊 & 玉洞堂正殿北側東南花警1 & 長洯 & - \\
\hline $560-A$ & 万字紋 & 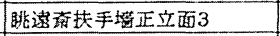 & 万蒎 & $395(\mathrm{H})$ & $641-G$ & 薄 & 玉澗堂正殷北側東南花盤2 & 長毒 & - \\
\hline $561-A$ & 药の花 & 眺遼献扶手缡正立面 4 & 国家泰平、国民平女 & $395(\mathrm{H})$ & $642-\mathrm{G}$ & 竹 & 宜芸門西南花䂏煉瓦 & 若タしい & - \\
\hline $562-A$ & 苼の花 & 眺透蒜扶手埢正立面5 & 国家秦平、国民平安 & $395(\mathrm{H})$ & $643-G$ & 䣦策 & 宜芸門北西花盤煉瓦 & 子孫万代 & - \\
\hline $563-A$ & 柿䒴榇 & 眺遼㛜扶手瑏正立面6 & 橲みが篹える & $395(\mathrm{H})$ & $644-G$ & 获 & 宜芸馆正段西南花䈣㶱瓦 & 長拏 & - \\
\hline $564-A$ & 警甲瀪 & 眺透㟥扶手境正立面7 & 長奉 & $395(\mathrm{H})$ & $645-G$ & 犽 & 宜芸馆正殷束南花珡煉瓦 & 長毒 & - \\
\hline $565-\mathrm{A}$ & 蔡·毒石 & 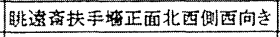 & 綎摩長㸷 & $295 \times 740$ & & & & & \\
\hline $566-\mathrm{A}$ & 忘れな草、邦石 & 眺遗裔扶手淁正面北西侧北向圭 & 男性に良く、益寿 & $295 \times 740$ & & & 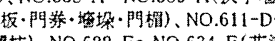 & NO.613-D ( 影㖏-山花 & $10.614-\mathrm{E} \sim$ \\
\hline $567-A$ & 菊・絜石 & 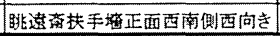 & 键康長传 & $295 \times 740$ & No.621- & 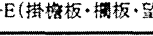 & 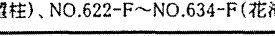 & 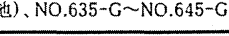 & 年 \\
\hline
\end{tabular}

